\title{
PERFORMANCE ASSESSMENT SEBAGAI INSTRUMEN PENILAIAN UNTUK MENINGKATKAN KETRAMPULAN PROSES pada PRAKTIKUM KIMIA DASAR DI TADRIS KIMIA
}

\section{Ervin Tri Suryandari}

\begin{abstract}
Abstrak
Penilaian terpadu yang komprehensif dan seimbang antara proses dan hasil belajar tersebut dilaksanakan dalam kerangka Penilaian Berbasis Kelas (PBK). Kimia merupakan ilmu yang diperoleh dan dikembangkan berdasarkan eksperimen, sehingga metode eksperimen sangat penting diterapkan dalam pembelajaran kimia. Pembelajaran kimia menekankan pada pemberian pengalaman belajar secara langsung melalui penggunaan dan pengembangan keterampilan proses dan sikap ilmiah, sehingga performance assessment menjadi sangat penting. Proses penilaian dilakukan dengan langkah-langkah: perencanaan penilaian, pengumpulan informasi, pelaporan, dan penggunaan informasi tentang hasil belajar. Sebelum melaksanakan penilaian terhadap proses dan hasil belajar, guru harus membuat perangkat-perangkatnya agar penilaian yang dilakukan sesuai dengan kompetensi yang hendak diuji. Dalam makalah ini dibahas bagaimana mengembangkan instrumen untuk performance assessment sebagai bentuk penilaian yang berkarakter kimia. Format instrumen dapat disusun dengan bentuk pedoman observasi, daftar cek, atau skala lajuan. Guru juga dapat mengembangkan instrumen performance assessment dengan rubrik yang lengkap. Meskipun penggunaan rubrik ini relatif menyita waktu, akan tetapi dengan rubrik yang lengkap guru dapat mengungkap kualitas dan profil performance peserta didik. Contoh rubrik yang dapat dikembangkan meliputi kompetensi merangkai alat, menggunakan alat, melakukan eksperimen, mengelola zat sisa, mempresentasikan hasil eksperimen, dan penilaian terhadap Laporan eksperimen.
\end{abstract}

Kata kunci : performance assessment, pembelajaran kimia, penilaian 


\section{PENDAHULUAN}

Jenis dan model penilaian yang digunakan sangat beragam tergantung pada jenis kompetensi, indikator hasil belajar yang ingin dicapai, materi pembelajaran dan tujuan penilaian itu sendiri. Adapun bentuk dan teknik penilaian yang biasa dilakukan dalam PBK adalah penilaian kinerja (performance assessment), penilaian penugasan (project), penilaian hasil kinerja (product), penilaian tes tertulis, penilaian portofolio dan penilaian sikap. Salah satu prinsip penilaian dilakukan oleh dosen dan mahasiswa. Hal ini perlu dilakukan bersama karena hanya dosen yang bersangkutan yang paling tahu tingkat pencapaian mahasiswa yang diajarnya.

Salah satu cara yang dapat dilakukan untuk mewujudkan PBK yaitu dengan mengkombinasikan penilaian kognitif yang berupa tes prestasi dengan penilaian kinerja (performance assessment). Penilaian kinerja (performance assessment) didapatkan dari hasil pengamatan dosen terhadap aktivitas mahasiswa sebagaimana yang terjadi. Penilaian biasanya digunakan untuk menilai kemampuan mahasiswa dalam diskusi pemecahan masalah, menggunakan alat-alat laboratorium dan aktivitas lain yang dapat diamati/diobservasi. Materi kimia berkaitan erat dengan kehidupan sehari-hari dan dapat dipraktikan sehingga metode eksperimen sangat penting diterapkan dalam pembelajaran kimia. Penerapan metode eksperimen dalam pembelajaran kimia memungkinkan diterapkannya performance assessment. Dalam makalah ini akan dibahas bagaimana mengembangkan instrumen untuk performance assessment sebagai bentuk penilaian untuk praktikum Kimia Dasar.

\section{Rumusan Masalah}

Rumusan masalah dari penelitian ini yaitu :

1. Bagaimana mengembangkan penilaian performance assessment sebagai bentuk penilaian praktikum Kimia Dasar di Tadris Kimia IAIN Walisongo?

2. Bagaimana respon mahasiswa terhadap mengembangkan penilaian performance assessment sebagai bentuk penilaian praktikum Kimia Dasar di Tadris Kimia IAIN Walisongo? 


\section{Tujuan Penelitian}

Berdasarkan pada rumusan permasalahan di atas, maka tujuan penelitian ini adalah:

1. Mengetahui efektifitas penilaian performance assessment sebagai bentuk penilaian berkarakter di Tadris Kimia IAIN Walisongo?

2. Mengetahui respon mahasiswa terhadap mengembangkan penilaian performance assessment sebagai bentuk penilaian berkarakter kimia di Tadris Kimia IAIN Walisongo?

\section{TINJAUAN PUSTAKA}

\section{Performance Assessment (Penilaian Kinerja)}

Asesmen secara ringkas didefinisikan sebagai penilaian terhadap proses perolehan, penerapan pengetahuan dan keterampilan, melalui proses pembelajaran yang menunjukkan kemampuan mahasiswa dalam proses maupun produk (Zainul, 2001: 4). Zainul (2001:8) juga menyatakan bahwa assessment kinerja adalah assessment yang mengharuskan mahasiswa mempertunjukkan kinerja, bukan menjawab atau memilih jawaban dari sederetan kemungkinan jawaban yang telah tersedia. Kinerja ini dapat berupa aktivitas mahasiswa dalam pembelajaran, benda hasil karya mahasiswa, ataupun hasil pemikiran mahasiswa yang dituangkan dalam bentuk lisan ataupun tulisan.

Trespeces (Setiadi; 2006:1) mengungkapkan bahwa asemen kinerja adalah berbagai macam tugas dan situasi dimana peserta tes diminta untuk mendemonstrasikan pemahaman dan pengaplikasian pengetahuan yang mendalam, serta keterampilan di dalam berbagai macam konteks. Sedangkan asesmen kinerja mahasiswa menurut Wulan (2000:9) adalah kegiatan penilaian yang dilakukan oleh dosen untuk menilai keterampilan mahasiswa dalam melakukan prosedur kerja laboratorium, menggunakan alat laboratorium, sikap dan hasil kerja praktikum. Namun pada penelitian ini, pengertian asesmen kinerja lebih mengacu kepada pengertian asesmen kinerja yang diungkapkan oleh Wulan yaitu merupakan penilaian dalam melakukan prosedur kerja laboratorium, menggunakan alat laboratorium, sikap dan hasil kerja praktikum karena berhubungan dengan kegiatan praktikum. 
Menurut Linn \& Gronlund (Hidayat,2007:13) keuntungan menggunakan performance assessment adalah bahwa performance assessment mampu

(1) mengkomunikasikan secara jelas tujuan instruksional yang melibatkan kinerja kompleks dalam lingkungan sebenarnya baik di dalam maupun di luar sekolah

(2) mengukur hasil belajar yang tidak dapat diukur oleh alat ukur lainnya

(3) memberikan alat penilaian proses dan produk

(4) implementasi pendekatan yang disarankan oleh teori belajar modern.

Andrade (Zainul 2001: 19) mendefinisikan rubric is a scoring to olthatliststhe criteria for a piece of work, or what counts. Penggunaan rubrik dalam assessment kinerja sangat penting karena asesmen kinerja tidak menggunakan kuncijawaban yang menentukan suatu kinerja benar atau salah seperti yang biasa dilakukan dalam tes (Zainul, 2001: 20). Dengan demikian rubric dapat digunakan untuk mengevaluasi apakah penilaian kinerja tersebut sudah dapat dianggap berkualitas baik, maka paling tidak harus diperhatikan tujuh kriteria membantu dosen untuk menentukan tingkat ketercapaian kinerja yang diharapkan. Zainul (2001: 22) mengungkapkan, setidaknya ada beberapa elemen yang harus ada pada rubrik, yaitu:

1. Dimensi, yang akan dijadikan dasar menilai kinerja mahasiswa;

2. Definisi dan contoh, yang merupakan penjelasan mengenai setiap dimensi

3. Skala yang akan digunakan untuk menilai dimensi;

4. Standar untuk setiap kategori kerja.

Untuk mengevaluasi apakah penilaian kinerja tersebut sudah dapat dianggap berkualitas baik, maka paling tidak harus diperhatikan tujuh criteria

1. Generability, artinya adalah apakah kinerja peserta tes dalam melakukan tugas yang diberikan tersebut sudah memadai un- 
tuk digeneralisasikan kepada tugas-tugas lain. Semakin dapat digeneralisasikan tugas-tugas yang diberikan dalam rangka penilaian keterampilan atau penilaian kinerja tersebut atau semakin dapat dibandingkan dengan tugas lainnya maka semakin baik tugas tersebut. Hal ini terutama dalam kondisi bila para peserta tes diberikan tugas-tugas dalam bentuk keterampilan yang berlainan.

2. Authenticity, artinya apakah tugas yang diberikan tersebut sudah serupa dengan apa yang sering dihadapinya dalam praktek kehidupan sehari-hari.

3. Multiple foci, artinya apakah tugas yang diberikan kepada peserta tes sudah mengukur lebih dari satu kemampuan-kemampuan yang diinginkan (more than one instructional outcomes).

4. Teachability, artinya tugas yang diberikan merupakan tugas yang hasilnya semakin baik karena adanya usaha mengajar dosen di kelas. Jadi tugas yang diberikan dalam penilaian keterampilan atau penilaian kinerja adalah tugas-tugas yang relevan dengan yang dapat diajarkan dosen didalam kelas.

5. Fairness, artinya apakah tugas yang diberikan sudah adil untuk semua peserta tes. Jadi tugas-tugas tersebut harus sudah dipikirkan tidak "bias" untuk semua kelompok jenis kelamin, suku bangsa, agama, atau status sosial ekonomi.

6. Feasibility, artinya apakah tugas-tugas yang diberikan dalam penilaian keterampilan atau penilaian kinerja memang relevan untuk dapat dilaksanakan mengingat faktor-faktor seperti biaya, ruangan (tempat), waktu, atau peralatannya.

7. Scorability, artinya apakah tugas yang diberikan nanti dapat diskor dengan akurat dan reliabel. Karena memang salah satu yang sensitif dari penilaian keterampilan atau penilaian kinerja adalah penskorannya.

Selain kriteria-kriteria yang harus diperhartikan dalam mengevaluasi asesmen kinerja, Setiadi (2006:6) mengemukakan langkah-langkah yang perlu diperhatikan yaitu asesmen kinerja tidak menggunakan kunci jawaban dalam menentukan skor, melainkan 
menggunakan pedoman penskoran berupa rubrik. Untuk menjamin reliabilitas, keadilan dan kebenaran penilaian maka perlu dikembangkan kriteria atau rubrik untuk pedoman menilai hasil kerja pebelajar. Rubrik dapat disusun bersama dengan pebelajar, sehingga jelas dasar yang dipakai untuk menilai

Tes essay merupakan contoh yang sangat umum dari suatu asesmen berbasis kinerja, tetapi ada banyak contoh lain, meliputi produksi artistik, eksperimen dalam sains, presentasi lisan, dan menggunakan matematika untuk menyelesaikan masalah dunianyata. Penekanan pada melakukan, tidak hanya mengetahui; pada proses dan juga produk. Selain itu, asesmen dari kemampuan mahasiswa untuk membuat observasi, memformulasikan hipotesis, mengumpulkan data, dan menggambarkan konklusi saintifik valid dapat membutuhkan penggunaan asesmen kinerja. Assessmen kinerja menentukan suatu basis bagi dosen dengan mengevaluasi keefektivan proses atau prosedur yang digunakan (misalnya pendekatan untuk pengumpulan data, manipulasi instrumen) dan produk yang dihasilkan dari kinerja suatu tugas (misalnya, laporan hasil lengkap, senikerja lengkap) (Jacob, 2011).

Asesmen kinerja seringkali menunjuk pada assessment otentik dengan menekankan bahwa dosen mengases kinerja sementara mahasiswa terlibat dalam pemecahan masalah dan pengalaman belajar yang dinilai dalam kebenaran diri mereka sendiri, bukan sebagai makna menilai prestasi mahasiswa. Bagaimanapun, tidak semua asesmen kinerja adalah otentik dalam pengertian bahwa dosen melibatkan mahasiswa dalam menyelesaikan masalah real (Linn \& Gronlund, 1995:13) dalam Jacob (2011). Asesmen kinerja diperlukan mahasiswa untuk mendemonstrasikan keterampilan dengan melakukan secara aktual. Assessment kinerja diperlukan untuk mengobservasi dan evaluasi keterampilan.

Assessment kinerja pada prinsipnya lebih ditekankan pada proses keterampilan dan kecakapan dalam menyelesaikan tugas yang diberikan. Asesmen ini sangat cocok digunakan untuk menggambarkan proses, kegiatan, atau unjuk kerja. proses, kegiatan, atau unjuk kerja dinilai melalui pengamatan terhadap mahasiswa ketika melakukannya. Penilaian unjuk kerja adalah penilaian berdasar- 
kan hasil pengamatan penilai terhadap aktivitas mahasiswa sebagaimana yang terjadi. Misalnya penilaian terhadap kemampuan mahasiswa merangkai alat praktikum untuk percobaan sederhana dilakukan selama mahasiswa merangkai alat, bukan sebelum atau setelah alat dirancang.

Assessment ini melibatkan aktivitas mahasiswa yang membutuhkan unjuk keterampilan tertentu dan/atau penciptaan hasil yang telah ditentukan. Karena itu, metodologi Assessment ini memberi peluang kepada dosen untuk menilai pencapaian berbagai hasil pendidikan yang sebenarnya tidak dapat dijabarkan dalam tes tertulis. Melalui metodologi ini, Assessment kinerja memungkinkan dosen mengamati mahasiswa saat mahasiswa sedang bekerja atau melakukan tugas belajar, atau dosen dapat menguji hasil-hasil yang dapat dicapai, serta menilai (judge) tingkat penguasaan/kecakapan yang dicapai mahasiswa (UPI, 2011).

Assessment kinerja tidak hanya bergantung pada jawaban benar atau salah. Sebagaimana halnya dengan asesmen bentuk essay, observasi yang dilakukan oleh dosen dalam rangka melakukan pertimbangan-pertimbangan subyektif berkenaan dengan level prestasi yang dicapai mahasiswa. Evaluasi ini didasarkan pada perbandingan kinerja mahasiswa dalam mencapai standar excellent (keunggulan, prestasi) yang telah dicapai sebelumnya (UPI, 2011).

Sebagaimana tes essay, pertimbangan dosen digunakan sebagai dasar penempatan kinerja mahasiswa pada suatu kesatuan/ kontinum tingkatan-tingkatan prestasi yang terentang mulai dari tingkatan yang sangat rendah sampai tingkatan yang sangat tinggi. Hal-hal yang harus kita pahami tentang asesmen kinerja adalah kita mendesain dan mengembangkan asesmen kinerja untuk digunakan kelak di kelas kita sendiri. Metodologi assessment kinerja bukanlan suatu obat yang mujarab, bukan penyelamat dosen, dan juga bukan merupakan suatu kunci untuk menilai kurikulum yang sebenarnya. Assessment ini semata-mata merupakan alat yang memberikan caracara yang efisien dan efektif untuk menilai beberapa (bukan keseluruhan) hasil-hasil dari proses pendidikan yang dipandang berguna (UPI, 2011). 


\section{METODOLOGI}

Penelitian yang akan dilakukan merupakan penelitian kuantitatif dengan analisa statistika deskriptif untuk memberikan gambaran terhadap objek yang diteliti.

1. Subjek dan Objek Penelitian

Subjek penelitian ini adalah mahasiswa Program Studi Tadris Kimia Fakultas Tarbiyah IAIN Walisongo yang mengikuti mata kuliah Praktikum Kimia Dasar Tahun Akademik 2011/2012. Objek penelitiannya adalah kompetensi mahasiswa yang terdiri atas 3 kompetensi yaitu kemampuan kognitif, afektif (sikap) dan psikomotorik (keterampilan) ilmiah yang diukur dengan instrumen yang telah disiapkan.

2. Metode Pengumpulan Data

Metode penelitian ini adalah penelitian kuantitatif dimana peneliti menentukan objek yang diteliti menggunakan pertanyaan yang spesifik, mengumpulkan data numerik, dengan analisa data menggunakan metode statistika. Data dikumpulkan melalui observasi, pemberian tes dan angket. Observasi digunakan untuk mengetahui keterampilan dan sikap ilmiah selama proses responsi dengan menggunakan tes petik kerja (work sample). Angket digunakan untuk mengetahui sikap ilmiah mahasiswa. Tes digunakan untuk mengetahui kemampuan kognitif mereka pada topik yang diberikan.

Instrumen ini digunakan untuk mengukur aspek afektif dan psikomotor mahasiswa dengan pengamatan langsung. Aspek afektif yang diamati adalah keaktifan, kekritisan (bertanya/ menjawab), kerja sama, tanggung jawab, kedisiplinan, kerapian, dan kebersihan, sedangkan aspek psikomotor yang diamati adalah ketrampilan menggunakan/merangkai alat, melakukan kerja/percobaan, dan mengamati/ mencatat data. Tes kognitif dilakukan dengan menggunakan metode tes, yang terdiri dari pre-tes dan post-test. Pretest dilakukan sebelum mahasiswa memperoleh materi praktikum kimia dasar.

3. Metode Analisis Data

Data hasil penelitian dari aspek kognitif dianalisis menggunakan analisa statistik. Metode analisis data yang kami gu- 
nakan adalah metode statistik deskriptif untuk data hasil belajar afektif dan psikomotorik

Pada analisis tahap akhir ini, digunakan data hasil belajar afektif dan psikomotorik. Analisis yang digunakan adalah analisis deskriptif, yang bertujuan untuk mengetahui nilai afektif dan psikomotorik mahasiswa.

\section{HASIL DAN PEMBAHASAN}

\section{Analisa Data}

Pelaksanaan penilaian pada semua perkuliahan praktikum kimia di Jurusan Kimia termasuk Praktikum Kimia Dasar masih didasarkan pada pencil and paper test saja. Akibatnya status yang diperoleh mahasiswa tidak sesuai dengan keterampilannya di laboratorium. Banyak terjadi, mahasiswa yang memiliki keterampilan yang baik saat melakukan praktikum (ditunjukan dengan akurasi hasil praktikum, tingginya rendeman yang diperoleh, dan sebagainya) namun mendapatkan nilai yang kurang dibandingkan mahasiswa yang kurang terampil di laboratorium tetapi nilai tes tertulisnya lebih baik. Fenomena ini tentu tidak fair bagi beberapa mahasiswa yang terampil, mengingat keterampilan laboratorium tidak bisa dikuasai hanya dengan penguasaan teori semata.

Penelitian ini diawali dengan melakukan praktikum seprti biasa tetapi tanpa sepengetahuan mahasiswa, dosen dibantu oleh asisten melakukan penilaian menggunakan format penilaian unjuk kerja (performance assessment). Ada kecenderungan bahwa mahasiswa hanya melakukan praktikum apa adanya dengan asumsi atau target bahwa mereka akan mempersiapkan diri untuk menghadapi ujian akhir berupa ujian tulis agar mendapatkan nilai yang baik. Pada penelitian ini dilakukan penilaian mulai dari awal praktikan masuk sampai selesai mngerjakan praktik. Tahap awal adalah

1. Tahap Persiapan :

Penilaian aspek kinerja tahap persiapan mahasiswa meliputi datang tepat waktu, membawa perlengkapan praktikum (alat/bahan yang ditugaskan), memakai jas lab dan menggunakan APD/alat pelindung diri. 
2. Tahap Proses Kegiatan Praktikum

Pada tahap proses ini ada 2 aspek :

a. Aspek menggunakan alat dan bahan meliputi mengambil bahan denfan rapi tidak berceceran, mengambil bahan praktikum sesuai kebutuhan, mengoperasikan alat dengan benar, menggunakan alat dan bahan sesuai prosedur praktikum)

b. Aspek kemauan, ketrampilan, mengamati, menganalisis dan menyimpulkan hasil praktikum meliputi :

- Memfokuskan perhatian pada kegiatan praktikum/tidak mengerjakan hal-hal lain

- Memiliki minat/interest terhadap aktifitas praktikum

- Terlibat secara aktif dalam kegiatan praktikum

- Mengamati hasil praktikum dengan cermat

- Menyajikan data secara sistematis dan komunikatif

- Membuat kesimpulan yang sesuai dengan hasil praktikum (sementara)

3. Tahap Kegiatan akhir praktikum

Pada tahap kegiatan akhir praktikum meliputi, membersihkan alat yang telah dipakai, membersihkan meja praktikum dari sampah dan bahan yang telah dipakai, mengembalikan alat ke tempatnya semula dalam keadaan kering.

Dari ketiga aspek tersebut diterapkan pada percobaan pertama/praktikum pertama dan percobaan ke 4 , dengan maksud dengan $4 x$ praktikum mereka sudah terbiasa dan bisa melakukan praktikum dengan benar. Sata hasil observasi sebagaimana tercantum dalam gambar 4.1 berikut ini.

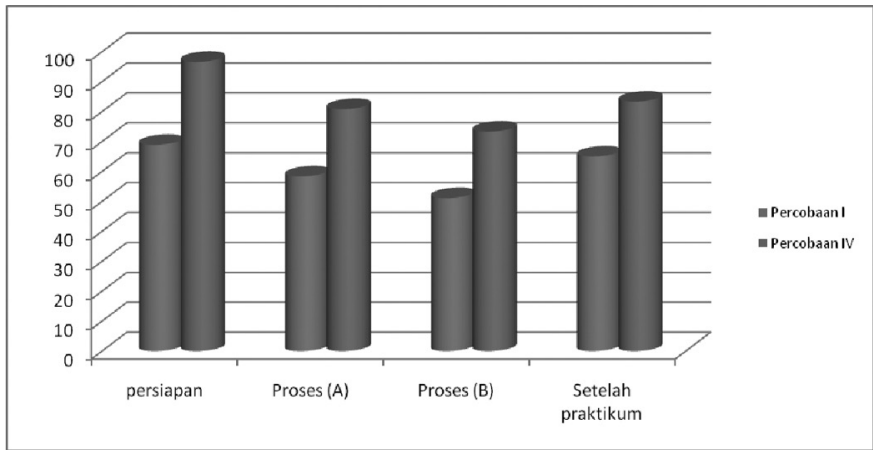


Dari tabel diatas dapat dilihat bahwa tiap aspek pada tahap persiapan praktikum, masih banyak nilai yang rendah ini bisa diartikan banyak mahasiswa yang datang terlambat, ada yang tidak membawa perlengkapan praktikum (alat/bahan yang ditugaskan oleh dosen, dan juga masih ada yang tidak memakai jas laboratorium dan walaupun memakai tetapi tidak digunakan sebagaimana seharusnya.Pada saat praktikum mahasiswa juga masih terkesan asal praktikum selesai dan mendapatkan data dan kurang memperhatikan bagaimana menggunakan alat yang benar, bagaimana memakai bahan kimia sesuai kebutuhan sehingga tidak banyak yang tersisa.

Pada saat praktikum selesai dilakukan mahasiswa berkewajiban membersihkan alat dan meja yang telah digunakan dan mengembalikannya ke tempat semula.. Pada praktikum saat ini mahasiswa sudah lumayan bagus walaupun masih ada yang tidak menjalankan tugas tersebut dengan baik, tetapi rata-rata kelas sudah bagus yaitu dengan 65. Sedangkan penilaian pada saat praktikum aspek kemauan, keterampilan mengamati menganalisis dan menyimpulkan hasil praktikum juga rata-rata masih kurang yaitu hanya 51,11.

Penilaian untuk tahap persiapan praktikum pada penilaian praktikum ke-4 ini mengalami kenaikan yang cukup drastis yang ditunjukkan oleh nilai rata-rata kelas 96,11 sedangkan sebelumnya hanya 68,89 . Hal ini menandakan bahwa mahasiswa semakin sadar dan bisa memenuhi kewajibannya saat persiapan praktikum yaitu datang tepat waktu, membawa perlengkapan praktikum (alat/bahan yang ditugaskan) dan menggunakan jas laboratorium dengan rapi dan benar.

Pada saat praktikum mahasiswa sudah tidak asal praktikum selesai dan mendapatkan data saja, hal ini bisa dilihat terjadi peningkatan nilai rata-rata kelas pada percobaan 4 yaitu sebesar 80,83 yang sebelumnya sebesar 58,33. Hal ini membuktikan bahwa mahasiswa sudah mampu menggunakan alat dengan baik dan benar, efisien memakai bahan kimia sesuai kebutuhan sehingga tidak banyak yang tersisa. Penilaian pada saat praktikum untuk aspek kemauan, keterampilan mengamati menganalisis dan menyimpulkan hasil praktikum juga mengalami peningkatan yaitu yang se- 
belumnya hanya 51,11 meningkat menjadi 73,33 . Pada saat praktikum selesai dilakukan mahasiswa berkewajiban membersihkan alat dan meja yang telah digunakan dan mengembalikannya ke tempat semula. Pada praktikum saat ini mahasiswa sudah bagus dan meningkat dari praktikum sebelumnyayang ditunjukkan oleh rata-rata kelas dari 65 meningkat menjadi 83,33.

Dari Gambar 4.1 menunjukan bahwa penerapan asesmen unjuk kerja dapat meningkatkan semangat mahasiswa untuk melakukan percobaan dengan benar dan hati hati, sehingga benar benar mengasah ketrampilan laboratorium mahasiswa. Hal ini menunjukan bahwa penerapan performance assessment atau unjuk kerja meningkatkan rasa tanggung jawab mahasiswa dalam melaksanakan praktikum. Tanggung jawab tersebut diwujudkan dalam bentuk efektivitas kerja dan efisiensi penggunaan bahan kimia yang cukup baik. Hal ini diperkuat dengan tingginya tingkat kerjasama dalam kelompok.

\section{Pembahasan}

Hasil penelitian menunjukan bahwa terjadi peningkatan yang cukup signifikan terhadap sikap positif mahasiswa dalam melaksanakan praktikum dari satu praktikum ke praktikum yang lain. Aspek kerjasama merupakan aspek yang sudah sangat baik, mengingat hal ini sudah sering dilakukan oleh mahasiswa dalam praktikum yang tidak menerapkan asesmen unjuk kerja sekalipun. Sehingga pola pendistribusian tugas dalam kelompok agar praktikum berlangsung efektif dan efisien sudah dipahami dengan baik oleh mahasiswa. Adapun aspek efisiensi penggunaan bahan kimia merupakan aspek paling jelek yang dilakukan oleh mahasiswa. Hal ini terjadi karena pada praktikum-praktikum sebelumnya aspek tersebut tidak pernah menjadi aspek penilaian sehingga mahasiswa terbiasa menggunakan bahan kimia secara berlebihan. Misalnya, meskipun yang dibutuhkan hanya sejumlah tertentu larutan, mahasiswa umumnya mengambil larut an dalam jumlah yang cukup besar dengan asumsi agar tidak kekurangan bagi kelompoknya. Namun akibatnya ada kelompok lain yang kekurangan sehingga laboran mesti melakukan preparasi bahan lagi. Fenomena ini sangat sering terjadi sebelumnya. Namun dengan penerapan 
asesmen unjuk kerja, mahasiswa menjadi lebih berhati-hati menggunakan bahan kimia sebagaimana ditunjukan pada pertemuan ke 4. Mahasiswa dengan kategori baik apabila saat berlangsungnya praktikum dan penilaian kinerja, mahasiswa melakukan setiap tahap eksperimen dengan benar, teliti dan hati-hati. Mahasiswa pada tahap persiapan praktikum melakukan datang tepat waktu, membawa perlengkapan praktikum (alat/bahan yang ditugaskan), memakai jas laboratorium dan berpakaian rapi. Pada saat praktikum berlangsung mahasiswa mengambil bahan dengan rapi tidak berceceran, mengambil bahan sesuai kebutuhan, mengoperasikan alat dengan benar, menggunakan alat dan bahan sesuai dengan prosedur. Fokus pada kegiatan praktikum, memiliki minat terhadap aktivitas praktikum, terlibat secara aktif dalam kegiatan praktikum, mengamati hasil praktikum dengan cermat membuat kesimpulan (sementara) yang sesuai dengan hasil praktikum. Dan pada akhir kegiatan praktikum mahasiswa tersebut membersihkan alat, meja yang telah dipakai dan mengembalikannya pada tempat semula. Mahasiswa dengan kategori kurang jika melakukan beberapa kesalahan, misalnya datang terlambat, menggunakan bahan kimia secara berlebihan, tidak fokus terhadap praktikum/melakukan kegiatan diluar kegiatan praktikum, dan lain lain.

Terbentuknya respon positif dari mahasiswa diperkuat oleh tingginya presisi dan akurasi hasil praktikum standarisasi $\mathrm{NaOH}$ dengan larutan standar asam oksalat yang diperoleh mahasiswa sebagaimana tercantum dalam tabel 4.2 berikut :

Tabel 4.2 . Hasil standarisasi $\mathrm{NaOH}$ dengan asam oksalat

\begin{tabular}{|c|c|c|}
\hline Titrasi ke- & V asam oksalat & V NaOH \\
\hline 1 & 10 & 9,9 \\
\hline 2 & 10 & 9,8 \\
\hline 3 & 10 & 9,9 \\
\hline Rata-rata & 10 & 9,86 \\
\hline
\end{tabular}

Berapa konsentrasi $\mathrm{NaOH}$ ?

Dari hasil perhitungan diperoleh konsentrasi $\mathrm{NaOH}$ adalah 0,101 N, sedangkan normalitas $\mathrm{NaoH}$ yang sebenarnya adalah 0,1 
N. Dari data tersebut di atas dapat ditarik kesimpulan bahwa hasil praktikum mahasiswa menunjukkan akurasi dan presisi yang tinggi. Adapun tingkat obyektivitas mahasiswa dalam menilai kinerjanya sendiri tergolong sangat bagus. Hal ini tergambar dari pencocokan format evaluasi diri yang diberikan dengan foto hasil eksperimen yang ada di kelompoknya masing-masing.

Sebagai contoh pada praktikum standarisasi $\mathrm{NaOH}$ dengan asam oksalat ada mahasiswa yang melaporkan bahwa hasil titrasinya tidak berwarna pink (merah muda) tapi merah seperti yang ditunjukkan dalam gambar 4.1 dan gambar 4.2 berikut:

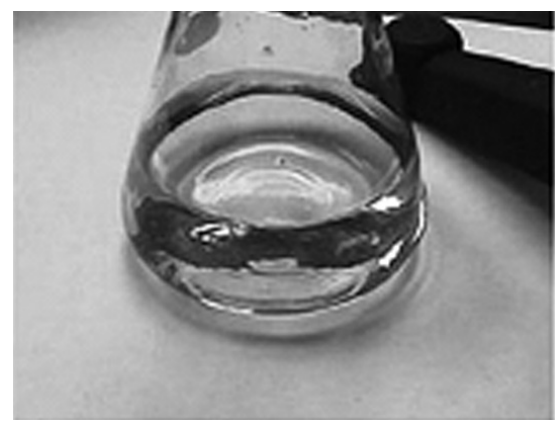

Gambar 4.1

Hasil titrasi sesuai teori

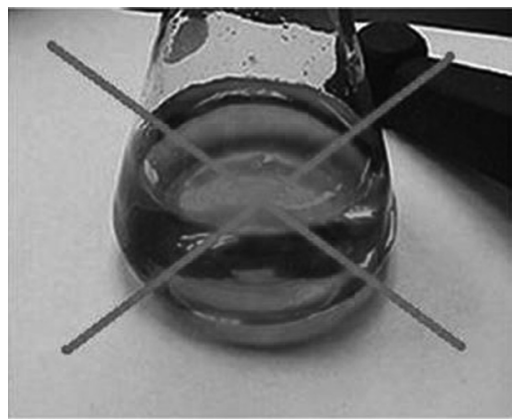

Gambar 4.2

Hasil titrasi hasil percobaan

Pada gambar 4.1 dan 4.2 ditunjukkan bahwa hasil percobaan dilakukan secara obyektif, meskipun hasil yang diperoleh tidak sesuai dengan teori. Sikap obyektif ini merupakan sikap ilmiah yang senantiasa harus dipupuk dan dipelihara oleh mahasiswa sejak dini karena sikap ini menjadi salah satu cirri seorang ilmuwan khususnya kimiawan (berkarakter kimia).

Kemajuan sikap positif mahasiswa dalam melakukan eksperimen, presisi dan akurasi hasil percobaan serta tingkat obyektifitas mahasiswa dari satu praktikum ke praktikum selanjutnya.

Dari angket yang diberikan diakhir pertemuan dan hasilnya $80 \%$ praktikan/mahasiswa sangat setuju adanya pengembangan penilaian yang lebih komprehensif yaitu dengan menggunakan metode Performance Assessment, dan 75\% praktikan sangat setuju bahwa dengan penilaian model performance assessment ini dapat meningkatkan ketrampilan proses laboratorium. 


\section{KESIMPULAN DAN SARAN}

\section{Kesimpulan}

1. Performance Assesment merupakan pengembangan model penilaian khususnya untuk mata kuliah praktikum kimia Dasar yang bersifat menyeluruh (komprehensif), meliputi aspek kognitif, afektif dan psikomotorik, sehingga tujuan praktikum yang melatih ketrampilan laboratorium sebagai implementasi dari penilaian yang berkarakter kimia tercapai

2. Performance Assesment dalam praktikum Kimia Dasar memberikan pengaruh yang bagus terhadap sikap mahasiswa (kerjasama, tanggungjawab, efisiensi penggunaan bahan kimia,efektivitas kinerja, kebersihan, kerapihan, menarik kesimpulan) dalam melaksanakan praktikum.

3. Respon Mahasiswa sangat positif, hal ini ditunjukkan dengan $80 \%$ praktikan sangat setuju adanya pengembangan penilaian yang lebih komprehensif yaitu dengan menggunakan metode Performance Assessment, dan 75\% praktikan sangat setuju bahwa dengan penilaian model performance assessment ini dapat meningkatkan ketrampilan laboratorium.

\section{Saran}

1. Perlu dikembangkan rubrik performance assessment yang lebih ringkas, cermat dan dengan tingkat subyektifitas yang minimal

2. Perlu dikembangkan performance assessment untuk berbagai mata praktikum dengan mengembangkan indikator yang lebih sesuai 


\section{DAFTAR PUSTAKA}

BSNP. (2006). Panduan Penyusunan Kurikulum Tingkat Satuan Pendidikan Dasar dan Menengah. Jakarta: BSNP.

Asmawi Zainul. (2001). Alternative Assessment. Jakarta: PAU untuk Peningkatan Pengembangan Aktivitas Instruksional.

Masnur Muslich. (2007). KTSP Pembelajaran Berbasis Kompetensi dan Konteksual Panduan bagi Pendidik, Kepala Sekolah dan Pengawas Sekolah.Jakarta: Bumi Aksara.

Depdiknas. (2003). Pedoman Khusus Pengembangan Silabus dan Sistem Penilaian Berbasis Kompetensi untuk Sekolah Menengah Atas. Jakarta: Depdiknas.

Mimin Haryati. (2007). Model dan Teknik Penilaian pada KTSP. Jakarta: GP Press.

Mulyasa, E. (2006). Kurikulum Tingkat Satuan Pendidikan. Bandung: Rosda

Mulyati Arifin. (1994). Pengembangan Program Pengajaran Bidang Studi Kimia.

Surabaya: Airlangga University Press.

Sukardjo dan Rr. Lis Permana Sari. (2009). Penilaian Hasil Belajar Kimia. Yogyakarta: FMIPA UNY.

Suharsimi Arikunto, Prosedur Penelitian :Suatu pendekatan Praktik, Jakarta: Rineka Cipta, 2006

Tresna Sastrawijaya. (1998). Proses Belajar Mengajar Kimia. Jakarta : P2LPTK.

Joesmani, Pengukuran dan Evaluasi Dalam Pengajaran Depdikbud Dirjen Pendidikan Tinggi, Proyek Pengembangan, Lembaga Pendidikan Tenaga Kependidikan, Jakarta, 1988. 